\title{
Effect of recharging water from Meghna River on the arsenic contaminated groundwater
}

\author{
H. Masuda ${ }^{1}$, N. Hirai ${ }^{1}$ \& A.H.M. Selim Reza ${ }^{2}$ \\ ${ }^{1}$ Department of Biology and Geosciences, Osaka City University, Sumiyoshi-ku, Osaka, Japan \\ ${ }^{2}$ Department of Geology and Mining, University of Rajshahi, Rajshahi, Bangladesh
}

\begin{abstract}
Groundwaters and aquifer sediments from Chundpur and its surroundings, along the downstream Meghna River at the meeting with Padma River, Bangladesh, were analyzed to document the mechanism of As contamination. The As was released in association with infiltration of surface water into the shallow groundwater aquifer without strong reduction. In situ chemical weathering and the following desorption at increasing $\mathrm{pH}$ would be the primary and secondary processes to release As into the groundwater of the studied area.
\end{abstract}

\section{INTRODUCTION}

Delta plain at the south of Bangladesh is one of the most arsenic (As) affected area of the world. In this area, microbial activity is presumed to cause reduction-dissolution of As from the aquifer sediments to groundwater. The reduction-dissolution occurs during the infiltration of surface water into the aquifer. In this study, the geochemistry of groundwaters and aquifer sediments was studied to reveal the role of recharging water from rivers, especially the main channel of Meghna.

\section{STUDY AREA AND METHODS}

\subsection{Study area and sample collection}

Study area is at the east side of meeting of Meghna (Brahmaputra) and Padma (Ganges) Rivers (Fig. 1). The area is in the modern delta plain. In this area, as similar to the surrounding areas in this delta plain, highly As contaminated groundwater appears in the wells.

Ninty-nine groundwater and five river water samples were collected from the five villages (Fig. 1) in March 2016. The waters were collected in plastic and glass bottles and acidified if it was needed for the analyses. Water temperature, electric conductivity, $\mathrm{pH}$, ORP and DO were measured in situ. Aquifer sediments were cored from two sites down to $35 \mathrm{~m}$ depths using a split barrel sampler in May 2015.

\subsection{Laboratory analyses}

Major and minor element chemistry of water samples were analyzed in the laboratory. The anions were analyzed by ion-chromatography, and major cations and minor elements including As were analyzed by ICP-MS.

Total As and major element chemistry of whole sediment samples were analyzed by ICP-MS after alkali-fusion and X-ray fluorescence photometry respectively. Arsenic and the related elements of the sediments were also analyzed by differentially chemical extraction according to BCR method slightly modified to estimate the phases of mobile As (Rauret et al., 1999).

\section{RESULTS AND DISCUSSION}

\subsection{Water chemistry}

Major element chemistry was abundantly $\mathrm{Ca}-\mathrm{HCO}_{3}$ type in the three villages close to the Meghna River (MAT, CHU and FAR) and $\mathrm{Na}-\mathrm{HCO}_{3}$ type in the two inland villages (SHA and HAJ). In the all villages, groundwaters were occasionally affected by $\mathrm{Na}-\mathrm{Cl}$ type water, presumably originated from the household waster waters.

Arsenic concentration is generally high in the groundwaters $<70 \mathrm{~m}$ depths; the maximum concentration was $0.74 \mathrm{mg} \mathrm{L}^{-1}$. The groundwaters $>100 \mathrm{~m}$ depths were almost free from As. Riverwaters contained As $<5 \mu \mathrm{g} \mathrm{L}^{-1}$. Level of As is high in the HAJ, $\mathrm{CHU}$ and FAR villages, of which average As concentration of groundwaters from $<70 \mathrm{~m}$ depths wells were $0.44 \mathrm{mg} \mathrm{L}^{-1}$, indicating no relation of As level to the distance from the river. ORPs were the high of the groundwaters from FAR and HAJ compared with those of the other three villages, and the ranges of ORP did not directly related to the As concentration (Fig. 2). Especially, the groundwaters from HAJ gave wide variation of the ORP $(-20 \sim-155 \mathrm{mV})$ and high range of As $\left(0.24 \sim 0.63 \mathrm{mg} \mathrm{L}^{-1}\right.$ except one; $-90 \mathrm{mV}$ 


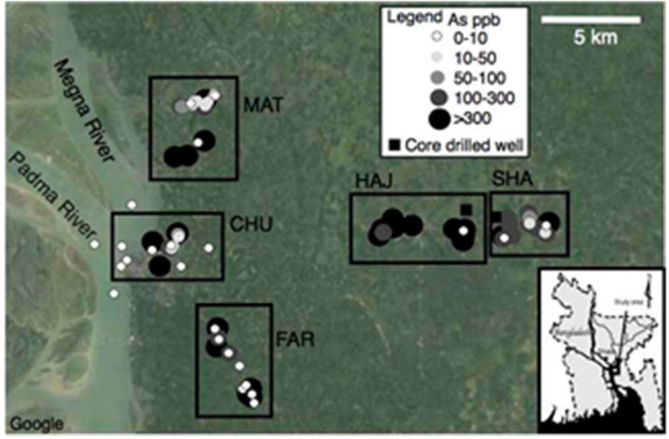

Figure 1. Study area and As concentration of groundwaters of Chandpur and its surroundings.

and $\left.0.006 \mathrm{mg} \mathrm{L}^{-1} \mathrm{As}\right)$. The groundwater giving the high ORP $(-20 \mathrm{mV})$ had $0.63 \mathrm{mg} \mathrm{L}^{-1}$ As. Iron concentration increased with decreasing ORP (not shown). Thus, in the studied area, reduction-dissolution of Fe-phases does not simply work to increase the As concentrations.

Major ion compositions of the groundwaters containing high As were mostly of $\mathrm{Ca}-\mathrm{HCO}_{3}$ type in the villages MAT, $\mathrm{CHU}$, and $\mathrm{FAR}$, while $\mathrm{Ca}-\mathrm{HCO}_{3}$ type in HAJ and SHA, indicating that the anthropogenic activity does not directly affect releasing As into the groundwaters of this area. Also, the high As groundwaters are rather diluted among the studied groundwater. It is suggested that the As is released from the sediments at the early stage of reaction between the infiltrating groundwater and minerals of the flowing paths.

\subsection{Mineralogy and sequential extracted chemistry}

As concentration had positive relationship to the XRD intensities of clay minerals, chlorite and mica, suggesting that certain amounts of As was adsorbed onto the fine fractions of aquifer sediments.

Two sets of core sediments taken from HAJ down to $23 \mathrm{~m}$ depths were analyzed by sequential chemical extraction. The total As concentration of the whole core sediments was within 2 and $8 \mathrm{ppm}$. Mobile compounds, categorized as weakly adsorbed, reducible and oxidizable fractions were 20 to $60 \%$ of the total As of the sediments. It is notable that the reducible phase, which means the As strongly adsorbed onto and/or fixed in Fe-oxyhydroxides and Mn-oxides, occupies the most abundant host phase of the As, although the mobile phases of As is smaller in the uppermost sediments than the lower ones. Considering increasing As concentration with increasing $\mathrm{pH}$, the level of As of the studied groundwater would be controlled by desorption from the Fe-oxyhydroxides and/or clay fractions

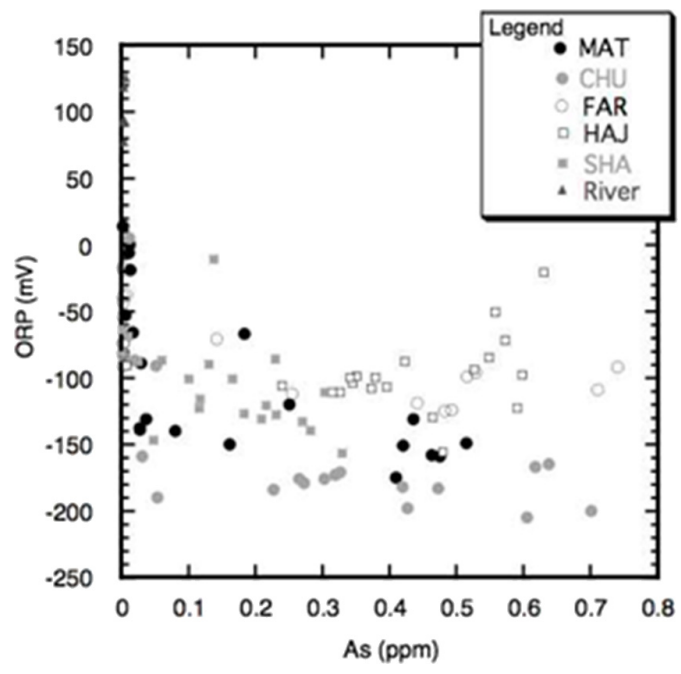

Figure 2. Relationship between As concentration and ORP of groundwaters from Chandpur and its surroundings.

with progressing chemical weathering. Dissolution of the Fe-oxyhydroxides as a host of As may follow the desorption.

\section{CONCLUSIONS}

Studied groundwaters would contain high As, which was released from the sediments via infiltration of river and/or local meteoric water to promote the chemical weathering and resulting increasing $\mathrm{pH}$ to desorb As from the Fe-oxyhydroxides and/or clay minerals as hosts of As in the studied groundwater aquifers. Chemical weathering must be an important mechanism of As releasing into the groundwater in the Neogene aquifers of the studied area.

\section{ACKNOWLEDGEMENTS}

We thank to T. Shimonaka and K. Okazaki, Osaka City University, and Drs. A. Marui and M. Ono, AIST, who supported the water analyses.

\section{REFERENCE}

Rauret, G., López-Sánchez, J.F., Sahuquillo, A., Rubio R., Davidson, C., Ure, A. \& Quevauvillerc, Ph. 1999. Improvement of the BCR three step sequential extraction procedure prior to the certification of new sediment and soil reference materials. J. Environ. Monit. 1: 57-61. 